\title{
Introductory lecture: Diagnosis of food allergy: when is an oral challenge positive
}

\author{
Bodo Niggemann \\ From Food Allergy and Anaphylaxis Meeting 2011 \\ Venice, Italy. 17-19 February 2011
}

Oral food challenges still remain the gold standard in the diagnosis of food related symptoms and are performed to obtain a clear "yes or no" response. However, this is often difficult to achieve, and so proposals may be appropriate for criteria on when to stop oral food challenges and declare a challenge as positive or negative. In daily practice it makes sense to challenge until clear objective symptoms occur without harming the patient. Clinical symptoms should be objective and/or: (a) severe or (b) reproducible or (c) persisting. A sensitive parameter for a beginning clinical reaction is a general change of mood. The sooner symptoms appear, the more likely they are to represent a "true" positive reaction, and the more organ systems are involved the easier it is to assess an oral food challenge as positive. In the case of subjective symptoms, the number of placebo doses should be increased. In unclear situations, the observation time until the next dose should be prolonged or the same dose repeated. Transient objective clinical symptoms usually end up in a positive challenge result. There are a number of causes for false positive and false negative challenge results, which should be considered. The aim of all oral challenge testing should be to hold the balance between two conflicting aspects: on the one hand the need to achieve clear and justified results from oral food challenges in order to avoid unnecessary diets, and on the other hand to protect patients from any harm caused by high doses of a potentially dangerous food.

Published: 12 August 2011

Pädiatrische Allergologie und Pneumologie, Hedwig-von-Rittberg-Zentrum, DRK-Kliniken Berlin, Berlin, Germany

\section{Biomed Central}

○ 2011 Niggemann; licensee BioMed Central Ltd. This is an open access article distributed under the terms of the Creative Commons Attribution License (http://creativecommons.org/licenses/by/2.0), which permits unrestricted use, distribution, and reproduction in any medium, provided the original work is properly cited.
doi:10.1186/2045-7022-1-S1-S43

Cite this article as: Niggemann: Introductory lecture: Diagnosis of food allergy: when is an oral challenge positive. Clinical and Translational Allergy 2011 1(Suppl 1):S43.
Submit your next manuscript to BioMed Central and take full advantage of:

- Convenient online submission

- Thorough peer review

- No space constraints or color figure charges

- Immediate publication on acceptance

- Inclusion in PubMed, CAS, Scopus and Google Scholar

- Research which is freely available for redistribution Submit your manuscript at
www.biomedcentral.com/submit C Biomed Central 